\title{
Comparative analysis of the methods of watermarking X-ray images
}

\section{Analiza porównawcza metod znakowania wodnego obrazów RTG}

\author{
Weronika Zofia Kulbaka**, Paulina Paluch**, Grzegorz Kozieł \\ Department of Computer Science, Lublin University of Technology, Nadbystrzycka 36B, 20-618 Lublin, Poland
}

\begin{abstract}
This paper is devoted to the comparative analysis of watermarking algorithms for X-ray images. The techniques based on discrete wavelet transform (DWT), singular value decomposition (SVD) and DWT-SVD hybrid were compared. Transparency, resistance to graphical transformations, and performance were investigated. The watermarked images were visually evaluated and quality tested. SVD showed the highest resistance to attacks, and the embedded watermarked images were of better quality in the comparison to the other algorithms. The DWT technique was the fastest, but not resistant to graphical transformations. In DWT-SVD labeled images, the watermark is indistinguishable, but the resistance to attacks is low. The SVD was found to be the most suitable method for watermarking of X-ray images.
\end{abstract}

Keywords: digital watermarks; security; steganography

\section{Streszczenie}

Artykuł poświęcono analizie porównawczej algorytmów znakowania wodnego obrazów RTG. Porównano technikę opartą na dyskretnej transformacie falkowej (DWT), metodę rozkładu wartości osobliwych (SVD) oraz hybrydę DWTSVD. Zbadano przezroczystość, odporność na przekształcenia graficzne, a także szybkości. Oznakowane obrazy poddano ocenie wizualnej oraz badaniu jakości. SVD wykazała największą odporność na ataki, a obrazy z osadzonym znakiem wodnym były lepszej jakości w porównaniu do obrazów oznakowanych za pomocą pozostałych algorytmów. Technika DWT była najszybsza, jednak nieodporna na przekształcenia graficzne. Na obrazach oznakowanych DWTSVD znak wodny jest niedostrzegalny, jednak odporność na ataki jest niska. Najodpowiedniejszą metodą do znakowania obrazów RTG okazała się metoda SVD.

Slowa kluczowe: cyfrowe znaki wodne; bezpieczeństwo; steganografia

${ }^{*}$ Corresponding author

Email address: weronika.kulbaka@pollub.edu.pl (W. Z. Kulbaka), paulina.paluch1@pollub.edu.pl (P. Paluch)

CPublished under Creative Common License (CC BY-SA v4.0)

\section{Wstęp}

Obecnie możliwe jest przesyłanie cyfrowych obrazów i danych medycznych przez Internet w celu rozpoznawania chorób i zdalnej diagnostyki pacjentów. W szybkim tempie wzrasta liczba przypadków fałszowania, manipulowania, usuwania i nieuprawnionego wykorzystywania danych medycznych. Obrazy medyczne, takie jak zdjęcia z diagnostycznych badań radiologicznych są istotnymi plikami, które należy dokładnie chronić. Istnieją różne metody znakowania wodnego obrazów RTG. Jednak niektóre z nich mogą skutkować utratą jakości lub znacząco wpłynąć na możliwość odczytania wyniku badań ze zdjęcia poprzez widoczność znaku wodnego. Zdjęcia rentgenowskie powinny być jak najlepszej jakości, a cyfrowe znaki wodne nie mogą wpływać na interpretację badania [1]. W tym celu zostanie przeprowadzona analiza wybranych trzech metod znakowania cyfrowego. Badanymi metodami będą: DWT (ang. Discrete Wavelet Transform - Dyskretna Tranformata Falkowa), SVD (ang. Singular Value Decomposition - Rozkład Wartości Pojedynczej) oraz hybryda DWT-SVD. Ponadto wyszczególniono następującą tezę i hipotezę badawczą:

T1: Istnieją metody znakowania wodnego obrazów medycznych pozwalające na uzyskanie odporności na popularne przekształcenia graficzne.
H1: Dobór odpowiedniego algorytmu znakowania wodnego pozwala na uzyskanie wysokiej przezroczystości osadzonego znaku wodnego.

Postawiono również następujące pytania badawcze:

1. Czy istnieje metoda znakowania wodnego, która umożliwia oznakowanie obrazu RTG bez utraty jakości?

2. Która $\mathrm{z}$ popularnych metod znakowania wodnego jest najbardziej odporna na popularne przekształcenia graficzne?

\section{Analiza literatury}

Bezpieczeństwo i ochrona praw autorskich treści cyfrowych jest obecnie bardzo trudną i istotną kwestią. Wynika to $\mathrm{z}$ dynamicznego rozwoju technologii multimedialnych umożliwiających łatwe przechowywanie, powielanie oraz rozpowszechnianie plików cyfrowych [1]. Obecnie występuje coraz więcej kradzieży tożsamości, nielegalnego kopiowania i dystrybucji danych, a także naruszeń prywatności. Autentyczność obrazów jest szczególnie ważna w dziedzinie medycyny. Obecnie możliwe jest przesyłanie cyfrowych obrazów i danych medycznych przez Internet $w$ celu rozpoznawania chorób i zdalnej diagnostyki pacjentów. W szybkim tempie wzrasta liczba przypadków fałszowania, manipulowania, usuwania i nieuprawnionego wykorzystywania danych medycznych. Opisana sytuacja wpływa na duże 
zainteresowanie skutecznymi i bezpiecznymi metodami zabezpieczania przesyłanych w sieci cyfrowych danych oraz ochronę praw autorskich.

W ostatnich latach powstało wiele prac naukowych w dziedzinie steganografii oraz znakowania wodnego obrazów. Jedni uczeni analizują istniejące techniki steganograficzne, inni identyfikują ograniczenia i braki tych metod oraz sprawdzają odporność na przekształcenia. Niektórzy weryfikują, które metody najlepiej sprawdzają się w zastosowaniu do obrazów medycznych. Jeszcze inni przedstawiają aktualne trendy oraz wyzwania, które będą podejmowane w przyszłości przez ludzi nauki.

W pracy naukowej „Digital image watermarking Techniques : a review" [4] autorzy przedstawili techniki znakowania wodnego obrazów (m. in. medycznych), takie jak LSB (ang. Least Significant Bit - Najmniej Znaczacy Bit), lub DCT (ang. Discrete Cosine Transform - Dyskretna Transformata Cosinusoidalna) i inne. Zweryfikowali oferowane przez nie właściwości, takie jak: niewykrywalność, bezpieczeństwo, niezawodność oraz pojemność steganograficzna wykonując różnego rodzaju przekształcenia oznakowanych obrazów medycznych. Przydatne okazały się również obliczenia wskaźników jakości zdjęć takie jak PSNR (ang. Peak Signal to Noise Ratio), SSIM (ang. Structural Similarity) czy też MSE (ang. Mean Square Error). Każda z badanych metod miała swoje mocne i słabe strony. Metoda DWT okazała się najlepsza pod względem wysokiej jakości znakowanego obrazu. Znak wodny był niezauważalny, jednak obraz nie był odporny na niektóre znane ataki. Metoda LSB była najszybsza, jednak nie zapewniała odporności na popularne zniekształcenia. Autorzy ocenili, że w sektorze zdrowia, najlepsze okazały się metody DWT, DCT oraz SVD.

Artykuł „A DWT-SVD based Robust Digital Watermarking for Digital Images" [3] w całości został poświęcony hybrydowej technice znakowania obrazów poprzez metodę DWT oraz SVD. Wyniki badań pokazały, że na obrazach oznakowanych techniką DWT-SVD znaki wodne były wizualnie niedostrzegalne. Algorytm ten zapewnia również wysoką odporność na ataki związane $\mathrm{z}$ przetwarzaniem obrazu.

Porównanie różnych technik zabezpieczania obrazów znakami wodnymi zawarto również $\mathrm{w}$ artykule „Watermarking techniques for medical data authentication: a survey" [2]. Autorzy przeanalizowali różne metody znakowania wodnego skupiając się przede wszystkim na obrazach medycznych np. zdjęciach z diagnostycznych badań radiologicznych. Opisali cechy charakterystyczne, najnowsze zastosowania oraz koncepcje osadzania i odzyskiwania znaku wodnego. Omówili również potencjalne wyzwania związane $\mathrm{z}$ osadzaniem znaków wodnych na obrazach medycznych. Autorzy podkreślili cechy, jakie powinny spełniać skuteczne techniki znakowania wodnego obrazów medycznych:

- bezpieczeństwo,

- niewykrywalność,

- odporność na uszkodzenia,

- niezawodność,
- szybkość.

Autorzy artykułu „Recent trends in image watermarking techniques for copyright protection: a survey" [11] opracowali wyniki dotyczące różnych technik znakowania wodnego obrazów, określili najnowsze praktyki z nimi związane oraz ich ograniczenia. Przedstawili również procentowy udział najczęściej używanych metod znakowania wodnego (Rys. 1). Najpopularniejsze okazały się metody DWT oraz SVD. Na trzecim miejscuw tej klasyfikacji uplasowała się technika DCT.

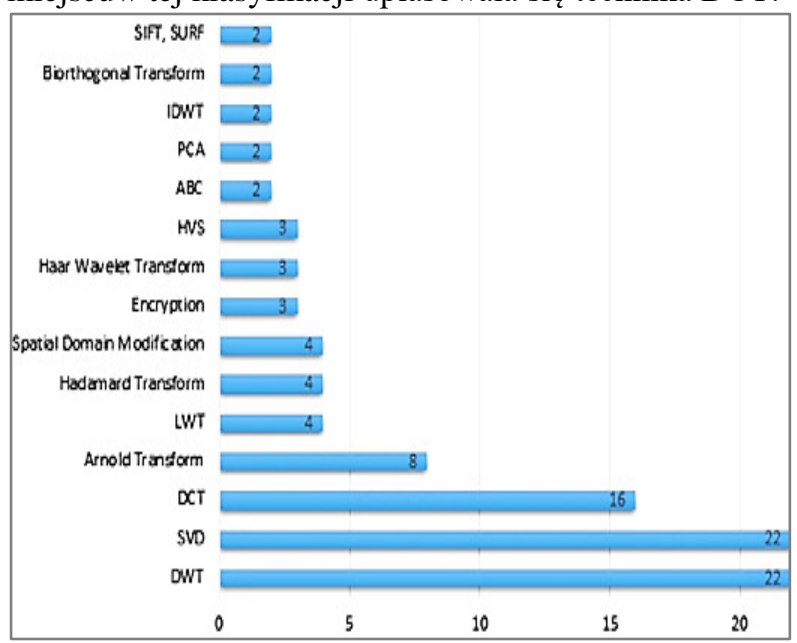

Rysunek 1: Najczęściej używane metody znakowania wodnego obrazów [11]

Inne porównanie technik znakowania wodnego opisali w swoim artykule Garg P. oraz Kishore R. Rama [6]. Przedstawili oni informacje na temat znaków wodnych pod względem ich charakterystyki, obszarów zastosowania, typów i różnych ataków na nie przeprowadzanych.

Ze względu na popularność metod zdecydowano się na przebadania dwóch najpopularniejszych $\mathrm{z}$ nich oraz ich połączenie - metodę DWT-SVD, która według literatury charakteryzuje się dobrymi właściwości znakowania. W prezentowanych badaniach użyte zostały zdjęcia RTG różnych części ciała osób dorosłych i dzieci.

\section{Metodyka badawcza}

Przygotowano zbiór 100 źródłowych obrazów RTG pochodzących z ogólnodostępnych baz danych obrazów medycznych [7, 8] oraz znak wodny w postaci logo Politechniki Lubelskiej w skali szarości. Na podstawie analizy literatury opracowano trzy wybrane algorytmy znakowania wodnego oraz wyodrębniania znaku wodnego $\mathrm{z}$ obrazów. Zaimplementowano również funkcje służące do realizacji określonych ataków na oznakowane obrazy takie jak obrót, rozmycie oraz wyostrzenie.

Cały zbiór obrazów źródłowych oznakowano za pomocą każdej z metod. Zestaw obrazów wynikowych zapisano do folderu znajdującego się w plikach źródłowych. Obrazy oznakowane za pomocą każdej z metod poddano badaniom oceny jakości za pomocą miar względnych oraz bezwzględnych takich jak:

- MSE - błąd średniokwadratowy, wartość oczekiwana podniesionej do kwadratu różnicy pomiędzy es- 
tymatorem, a wartością estymowaną [12]. Określany jest wzorem:

$$
M S E=\frac{1}{N \cdot M} \sum_{i=1}^{N} \cdot \sum_{j=1}^{M} \cdot\left(\left[f(i, j)-f^{\prime}(i, j)\right]^{2}\right)
$$

gdzie $N, M$ to wymiary obrazu w pikselach, $f(i, j)$ to wartość reprezetująca odcień piksela o współrzędnch $(i, j)$ obrazu oryginalnego, $f^{\prime}(i, j)$ to wartość reprezentująca odcień piksela o współrzędnych $(i, j)$ obrazu skompresowanego,

- PSNR - stosunek maksymalnej mocy sygnału do mocy zakłócającego szumu wyrażany w decybelach [12]. Używany jest do określenia jakości obrazu [13]. Określany jest wzorem:

$$
P S N R=10 \cdot \log _{10} \frac{[\max (f(i, j))]^{2}}{M S E}
$$

gdzie $\max (f(i, j))$ to wartość maksymalna danego sygnału,

- SSIM - miara prawdopodobieństwa strukturalnego służąca do pomiaru podobieństwa pomiędzy dwoma obrazami [12]. Miara między dwoma oknami $x$ oraz $y$ rozmiaru $N \times N$ jest wyznaczana wzorem:

$$
\operatorname{SSIM}(x, y)=\frac{\left(2 \mu_{x} \mu_{y}+c_{1}\right)\left(2 \sigma_{x y}+c_{2}\right)}{\left(\mu_{x}^{2}+\mu_{y}^{2}+c_{1}\right)\left(\sigma_{x}^{2}+\sigma_{y}^{2}+c_{2}\right)}
$$

gdzie $\mu_{x}$ to średnia z $x, \mu_{y}$ to średnia z $y, \sigma_{x}^{2}$ to wariancja z $x, \sigma_{y}^{2}$ to wariancja z $y, \sigma_{x y}$ to kowariancja z $x$ oraz $y, c_{1}=\left(k_{1} L\right)^{2}, c_{2}=\left(k_{2} L\right)^{2}$, gdzie $k_{1}$ oraz $k_{2}-$ stałe, $L$ - rozpiętość totalna wartości pikseli,

- MS-SSIM (ang. Multi-Scale SSIM) - popularna odmiana indeksu SSIM. Wykorzystuje podstawowy algorytm SSIM działając na kilku skalach,

- 3-SSIM (ang. Three-component SSIM) - zapewnia wyniki zgodne z ludzką subiektywnością przy określaniu jakości rozmytych i zaszumionych obrazów [12],

- NIQE (ang. Natural Image Quality Evaluator) naturalna miara jakości obrazu. Pozyskuje zestaw lokalnych cech obrazu, a następie dopasowuje wektory cech do modelu MVG (ang. Multivariate Gaussian) [10],

- PIQE (ang. Perception-based Image Quality Evaluator) - percepcyjny wskaźnik oceny jakości obrazu dla obrazów świata rzeczywistego [10],

- BRISQUE (ang. Blind/Referenceless Image Spatial Quality Evaluator) - niewidoczna/nieodnosząca się miara jakości obrazu przestrzennego. Wykorzystuje statystykę sceniczną (ang. scene statistic) lokalnie znormalizowanych współczynników luminacji do ilościowej oceny możliwych start "naturalności” obrazu spowodowanych obecnością zniekształceń [5].

W każdym przypadku wykonywano te same ataki $\mathrm{z}$ takimi samymi parametrami. Obrazy przekształcone zostały poddane analizie w celu określenia stopnia uszkodzenia dołączonych danych oraz możliwości odczytania dołączonego znaku wodnego i liczby przekła- manych bitów znaku wodnego. Uzyskane w wyniku znakowania obrazy również oceniono wyżej wymienionymi metrykami, a także wskaźnikiem liczby utraconych bitów BER (ang. Bit Error Rate).

Badania wykonywane były na laptopie Dell Inspiron z czterordzeniowym procesorem Intel Core i7-1065G7 oraz dyskiem SSD M.2 PCIe o pojemności 1TB. Laptop posiadał 16GB pamięci RAM oraz system operacyjny Microsoft Windows 10 Home w wersji 64-bitowej. Podczas przeprowadzania badań szybkości technik znakowania wodnego na komputerze działał tylko system operacyjny oraz oprogramowanie do znakowania wodnego.

W celu zapewnienia porównywalnych warunków prowadzenia badań wyłączono oprogramowanie antywirusowe, a komputer odłączono od sieci. Badania powtórzono 20 razy.

Wybrane do badań metody zaimplementowano w środowisku Matlab, zgodnie $\mathrm{z}$ algorytmami przedstawionymi przez ich autorów [1, 6, 9]. Opracowanych implementacji użyto do przeprowadzenia badań.

\section{Ocena jakości oznakowanych obrazów}

W procesie znakowania wodnego obrazów medycznych i innych bardzo ważne jest zachowanie odpowiedniego poziomu przezroczystości ukrywanego znaku wodnego. Wybierając odpowiednią metodę należy zwrócić uwagę na pogorszenie się jakości obrazu oraz występowanie zmian, które mogą wskazywać na istnienie dołączonego znaku [14]. W celu obiektywnego zbadania jakości obrazów z umieszczonymi znakami wodnymi wykorzystano metryki względne i bezwzględne, które oceniają w różny sposób jakość obrazu badając wielkość zakłóceń konkretnego typu [15].

Wartości poszczególnych wskaźników prawie nie zmieniają się w przypadku znaków wodnych o różnych rozmiarach. Zauważone różnice wartości mieszczą się w granicach błędów zaokrągleń. Spowodowane jest to implementacją algorytmów, które zawsze umieszczają znak wodny o maksymalnym dostępnym rozmiarze [16]. W przypadku zastosowania znaku wodnego o mniejszym rozmiarze jest on skalowany do rozmiaru obrazu znakowanego. Zdecydowano się na takie rozwiązanie, ponieważ w niniejszej pracy nacisk położono na badanie odporności znaku wodnego na uszkodzenia oraz określeniu maksymalnej dostępnej pojemności steganograficznej.

W tabelach 1, 2, 3 oraz 4 przedstawiono wartości średnie wybranych metryk dla zaimplementowanych technik znakowania wodnego oraz porównanie wizualne. Do badania użyto 40 obrazów o rozmiarze około $100 \mathrm{~KB}$. Znakowano je znakiem wodnym o rozmiarze $100 \mathrm{~KB}$. Przed obliczeniem wartości średnich posortowano dane i odrzucono po $5 \%$ wyników najmniejszych i największych.

Najlepszy wynik dla pomiaru PSNR uzyskała metoda SVD - 42,5dB, a najgorszy metoda DWT - 31,4dB. Wyższa wartość wskaźnika PSNR oznacza mniejszy poziom zakłóceń wprowadzony do obrazu [12]. Wynika stąd, że oznakowanie obrazu RTG techniką SVD powo- 
duje najmniejszy spadek jakości zdjęcia w stosunku do pozostałych zaimplementowanych algorytmów.

Tabela 1: Średnie metryki względne oceny jakości obrazu oznakowanego różnymi metodami w stosunku do obrazu oryginalnego

\begin{tabular}{|c|c|c|c|c|}
\hline & $\begin{array}{c}\text { PSNR } \\
{[\mathrm{dB}]}\end{array}$ & SSIM & MS-SSIM & 3-SSIM \\
\hline DWT & 31,4 & 0,895 & 0,992 & 0,992 \\
\hline SVD & 42,5 & 0,990 & 0,995 & 0,995 \\
\hline DWT-SVD & 31,9 & 0,962 & 0,997 & 0,997 \\
\hline
\end{tabular}

Wartości wskaźników SSIM, MS-SSIM oraz 3SSIM przyjmują wartości [0,1], gdzie 0 oznacza całkowicie różne obrazy, a 1 - identyczne obrazy [10]. Dla wszystkich trzech metod znakowania wyniki wskazują na bardzo duże podobieństwo obrazu oznakowanego w stosunku do oryginału. W badaniu SSIM najgorzej wypadła metoda DWT, a najlepiej SVD. Natomiast w badaniach wskaźników MS-SSIM oraz 3-SSIM najlepszy wynik osiągnęła technika DWT-SVD. Przeprowadzono również ocenę wizualną. Na obrazach oznakowanych algorytmem SVD znak wodny nie jest widoczny, natomiast w przypadku zastosowania metody DWT dostrzegalne są kontury osadzonego logo, szczególnie na obszarach o ciemnym tle. Na większości obrazów oznakowanych techniką DWT-SVD znak wodny jest niewidoczny.

Tabela 2: Średnie metryki bezwzględne obrazów oryginalnych

\begin{tabular}{|c|c|c|}
\hline NIQE & PIQE & BRISQUE \\
\hline 4,2 & 15,3 & 19,8 \\
\hline
\end{tabular}

Tabela 3: Metryki bezwzględne obrazu oznakowanego wybranymi metodami

\begin{tabular}{|c|c|c|c|}
\hline & NIQE & PIQE & BRISQUE \\
\hline DWT & 4,0 & 15,3 & 18,8 \\
\hline SVD & 4,1 & 12,6 & 22,4 \\
\hline DWT-SVD & 4,1 & 16,3 & 19,3 \\
\hline
\end{tabular}

Badając jakość obrazów medycznych po umieszczeniu znaku wodnego można zastosować miary bezwzględne, ponieważ dostępne są zarówno obrazy oryginalne, jak i zniekształcone. Jedną z często stosowanych metryk jest NIQE (ang. Naturalness Image Quality Evaluator), czyli wskaźnik oceny tego, jak bardzo obraz zniekształcony jest podobny do oryginalnego [9]. Najlepszy wynik osiągnęła metoda DWT, jednak rezultaty dla pozostałych algorytmów różnią się od niej zaledwie o wartość 0,1. Wskaźnik PIQE (ang. Perception based Image Quality Evaluator) działa podobnie jak NIQE. Wynik PIQE to nieujemny skalar liczbowy z zakresu 1100. Jeśli wynik zawiera się w przedziale 0-20, jakość obrazu jest bardzo dobra, natomiast wynik z zakresu 81100 oznacza obraz bardzo słabej jakości [10]. Wynik dla obrazu oryginalnego wynosi 15,3. Wyniki uzyskane przez wszystkie analizowane metody są zbliżone i wskazują, że każda z nich zapewnia bardzo dobrą jakość obrazu. Wynik metryki BRISQUE (ang. Blind/Referenceless Image Spatial Quality Evaluator) jest również skalarem liczbowym z zakresu 1-100. Im niższa wartość, tym obraz jest lepszej jakości. Najbar- dziej jakość obrazu RTG spadła po umieszczeniu znaku wodnego algorytmem DWT, natomiast najwyższą jakość mają obrazy oznakowane metodą SVD, choć i tutaj różnica jest niewielka.

Analiza uzyskanych wyników wykazała, że najmniejsze zniekształcenia wprowadziła metoda SVD. Uzyskała ona najlepsze wartości wszystkich analizowanych wskaźników. Oznacza to, że obrazy oznakowane tą metodą będą zawierały najmniej zniekształceń a co za tym idzie będą najbardziej wartościowe $\mathrm{w}$ diagnostyce medycznej spośród obrazów oznakowanych pozostałymi badanymi metodami.

\section{Ocena wizualna oznakowanych obrazów}

Jednym ze sposobów oceny jakości oznakowanych obrazów jest przeprowadzenie subiektywnego testu, w którym tester ocenia każdy obraz $\mathrm{z}$ osadzonym znakiem wodnym $\mathrm{w}$ ustalonej skali. W niniejszej pracy ocenie poddano zbiór stu obrazów źródłowych porównanych do obrazów oznakowanych trzema badanymi algorytmami znakowania wodnego. Wyniki zaprezentowano

w tabeli 4. Oceniono zniekształcenia wprowadzone podczas znakowania wodnego w każdym z obrazów.

Użyto następującej skali:

1. zniekształcenia zupełnie niewidoczne,

2. zniekształcenia prawie niewidoczne,

3. zniekształcenia widoczne, nie przeszkadzające,

4. zniekształcenia widoczne, przeszkadzające,

5. obraz zniszczony.

Tabela 4: Wyniki oceny wizualnej obrazów oznakowanych poszczególnymi metodami

\begin{tabular}{|c|c|c|c|}
\hline & \multicolumn{3}{|c|}{$\begin{array}{c}\text { Procent obrazów, które otrzymały poszcze- } \\
\text { gólne oceny }\end{array}$} \\
\hline Ocena & $\begin{array}{c}\text { DWT } \\
{[\%]}\end{array}$ & $\begin{array}{c}\text { SVD } \\
{[\%]}\end{array}$ & $\begin{array}{c}\text { DWT-SVD } \\
{[\%]}\end{array}$ \\
\hline 1 & 5 & 100 & 100 \\
\hline 2 & 39 & 0 & 0 \\
\hline 3 & 55 & 0 & 0 \\
\hline 4 & 1 & 0 & 0 \\
\hline 5 & 0 & 0 & 0 \\
\hline
\end{tabular}

W wizualnej ocenie widoczności znaku wodnego najlepiej wypadła metoda rozkładu według wartości osobliwych oraz hybryda metod DWT i SVD. Ludzkie oko nie było w stanie zauważyć artefaktów znaku wodnego w obrazach oznakowanych tymi metodami. Natomiast $\mathrm{w}$ obrazach oznakowanych metodą DWT trudno było znaleźć przykłady, gdzie znak wodny byłby całkowicie niewidoczny. Wyniki uzyskane podczas oceny wizualnej odzwierciedlają wyniki uzyskane podczas oceny jakości za pomocą takich miar jak SSIM czy PSNR.

\section{Odporność na przekształcenia}

Technika znakowania wodnego stosowana do ochrony praw autorskich obrazów medycznych powinna być odporna na przekształcenia graficzne. Wybrano kilka najpopularniejszych przekształceń i przetestowano, jak radzą sobie $\mathrm{z}$ nimi zaimplementowane metody. 
W tym celu znakowano zdjęcia RTG, a następnie wyodrębniano obraz będący znakiem wodnym i badano wartość wskaźnika BER. Rezultaty badania odporności zaimplementowanych algorytmów na obrót oraz rozmycie zaprezentowano na wykresach i wyciągnięto wnioski.

\subsection{Badanie odporności na obrót}

Sprawdzono jak każda $\mathrm{z}$ technik radzi sobie z wyodrębnieniem znaku wodnego z obróconego oznakowanego obrazu medycznego (ang. rotation attack). Metodą prób i błędów wyszczególniono zakres dopuszczalnego kąta obrotu. Badanie przeprowadzono dla następujących wartości kąta obrotu obrazu: 0,01 stopnia, 0,1 stopnia, 0,5 stopnia, 10 stopni, 45 stopni, 90 stopni. Na rysunku 2 zaprezentowano oznakowany obraz oraz ten sam obraz obrócony o kąt 0,5 stopnia, natomiast na rysunkach 3, 4, 5 znajduje się znak wodny oryginalny porównany ze znakami wodnymi wyizolowanym $\mathrm{z}$ obróconych obrazów oznakowanych za pomocą badanych metod.

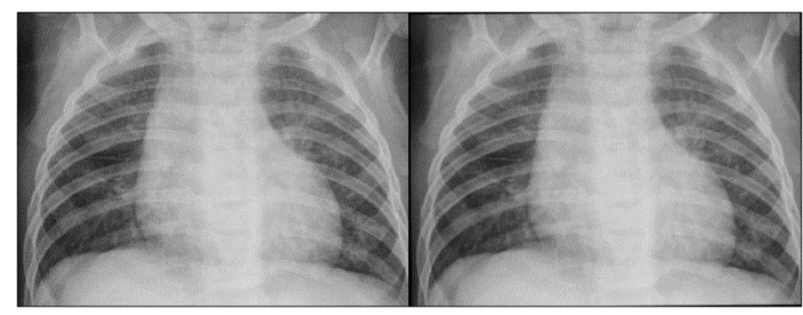

Rysunek 2: Oznakowany obraz prześwietlenia klatki piersiowej (po lewej) oraz to samo zdjęcie obrócone o 0,5 stopnia (po prawej).

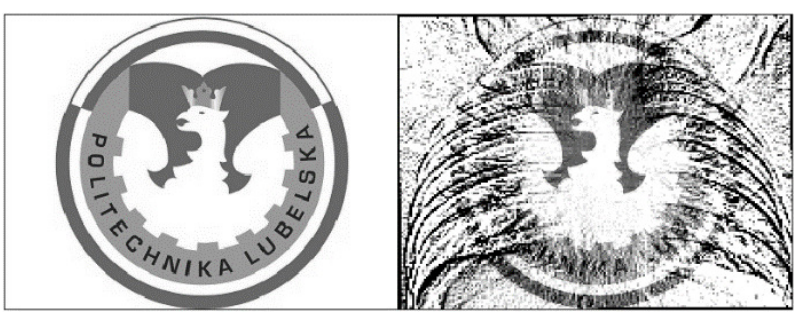

Rysunek 3: Znak wodny (po lewej) oraz wyizolowany znak wodny z obrazu (po prawej) oznakowanego metodą DWT i obróconego o 0,5 stopnia.

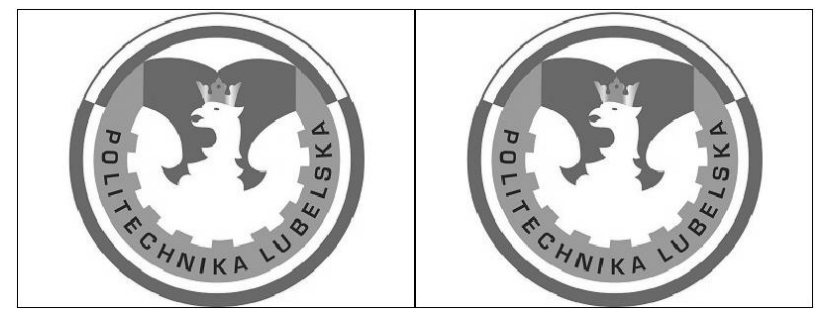

Rysunek 4: Znak wodny (po lewej) oraz wyizolowany znak wodny z obrazu (po prawej) oznakowanego metodą SVD i obróconego o 0,5 stopnia.

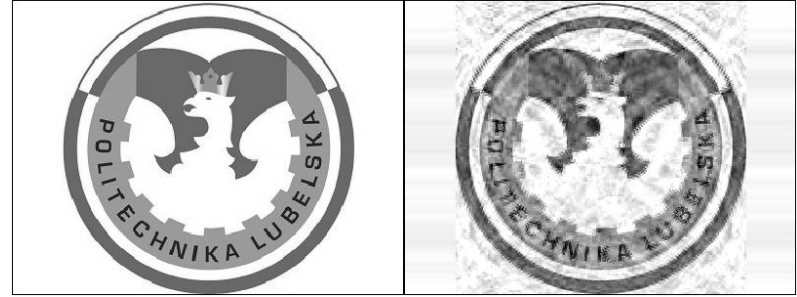

Rysunek 5: Znak wodny (po lewej) oraz wyizolowany znak wodny z obrazu (po prawej) oznakowanego metodą DWT-SVD i obróconego o 0,5 stopnia

$\mathrm{Na}$ logo Politechniki Lubelskiej wyodrębnionym z obróconego obrazu oznakowanego metodą DWT widoczne są żebra $\mathrm{z}$ prześwietlenia klatki piersiowej. Wyizolowanie znaku wodnego z obrazu RTG oznakowanego techniką SVD nie spowodowało utraty danych, natomiast w przypadku algorytmu DWT-SVD znak wodny jest lekko rozmazany. Wykresy zależności wskaźnika BER wyizolowanego znaku wodnego od kąta obrotu obrazu zaprezentowano na rysunkach 6, 7 i 8.

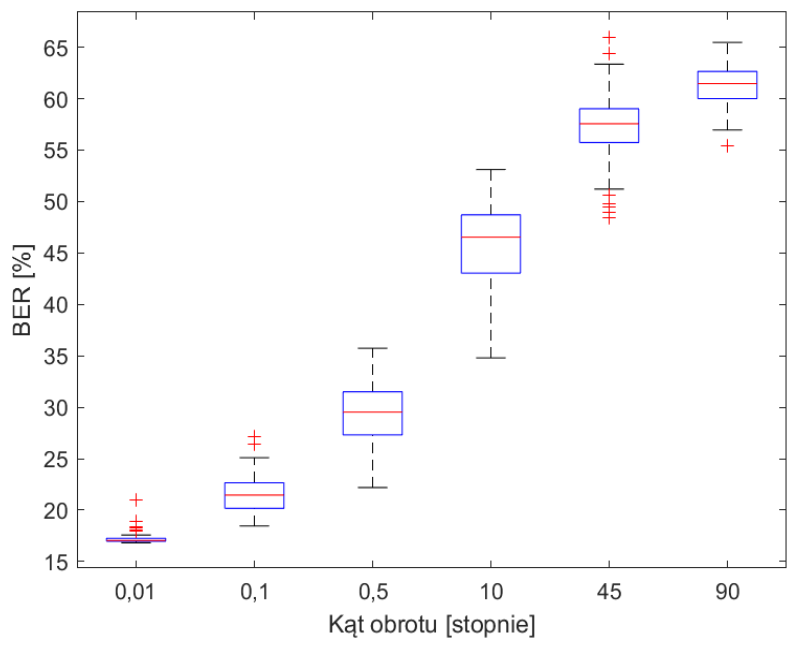

Rysunek 6: Wykres zależności wartości wskaźnika BER od kata obrotu obrazu dla metody DWT.

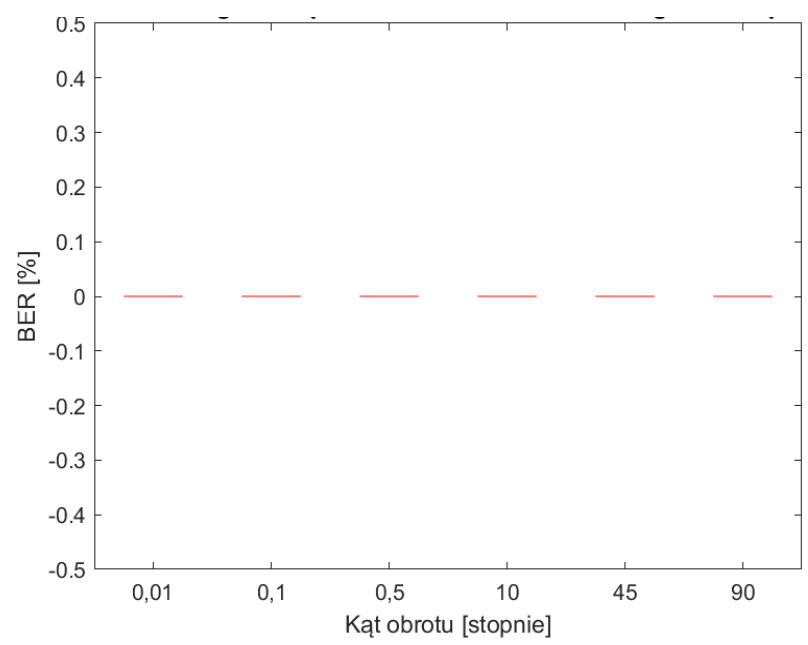

Rysunek 7: Wykres zależności wartości wskaźnika BER od kąta obrotu obrazu dla metody SVD. 


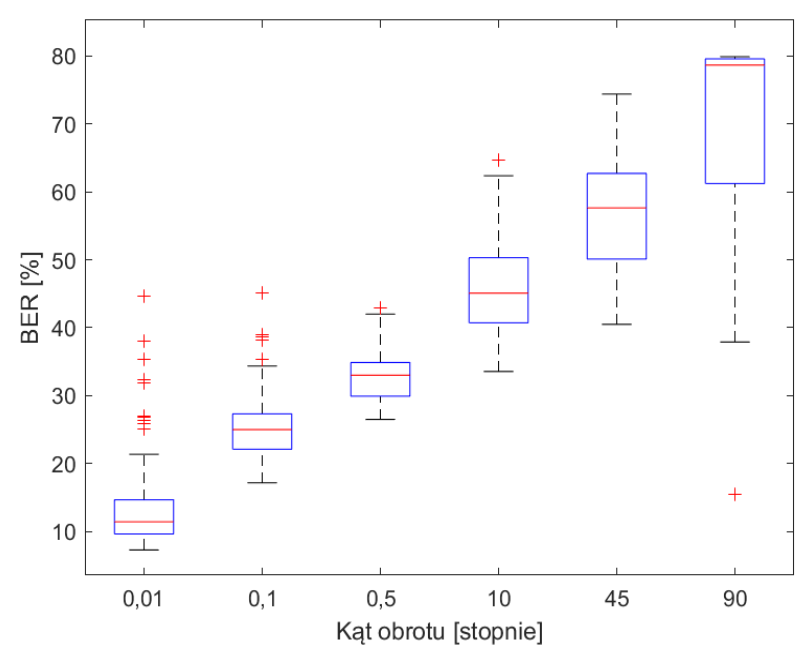

Rysunek 8: Wykres zależności wartości wskaźnika BER od kąta obrotu obrazu dla metody DWT-SVD.

\subsection{Badanie odporności na rozmycie}

W celu zbadania odporności na atak rozmycia (ang. motion attack) sprawdzono przy jak dużym rozmazaniu uda się wyodrębnić wizualnie niezniszczony znak wodny. Wykorzystana funkcja programu Matlab przyjmuje parametry: kąt przesunięcia (theta) oraz długość ruchu rozmycia (len). Przyjęto długość ruchu len=10. Rysunek 9 przedstawia porównanie obrazu oznakowanego dłoni $\mathrm{z}$ obrazem zaatakowanym rozmyciem, natomiast na rysunkach 10,11 i 12 porównania znaku wodnego ze znakiem wodnym wyodrębnionym z zaatakowanego obrazu.

Zależność wartości wskaźnika BER od liczby utraconych bitów prezentują wykresy pokazane na rysunkach 13, 14 i 15 . Najwyższą odporność na przekształcenie rozmycia wykazała technika SVD, natomiast metody DWT oraz DWT-SVD nie są odporne na ten atak, o czym świadczą zarówno zniekształcone znaki wodne, jak i znaczna utrata danych widoczna na wykresach.

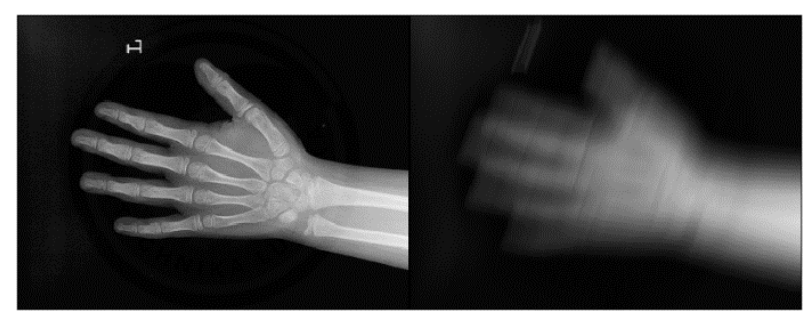

Rysunek 9: Oznakowany obraz prześwietlenia dłoni (po lewej) oraz to samo zdjęcie zaatakowane przekształceniem rozmycia (po prawej).

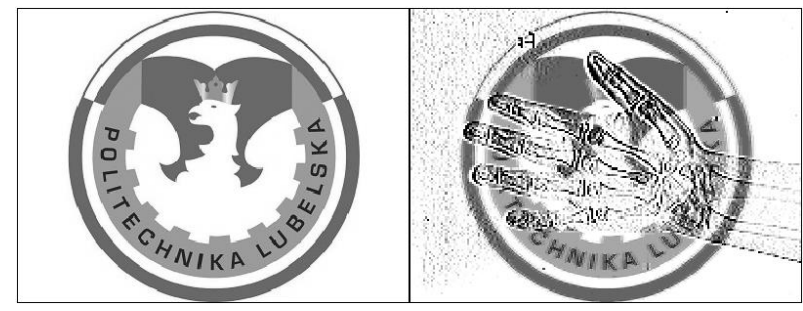

Rysunek 10: Znak wodny (po lewej) oraz wyizolowany znak wodny z rozmytego obrazu (po prawej) oznakowanego metodą DWT.

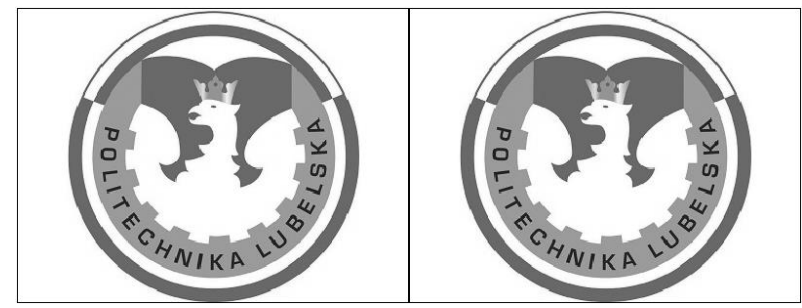

Rysunek 11: Znak wodny (po lewej) oraz wyizolowany znak wodny z rozmytego obrazu (po prawej) oznakowanego metodą SVD.

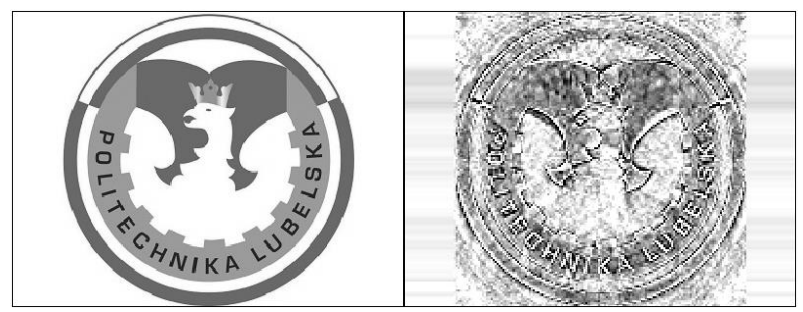

Rysunek 12: Znak wodny (po lewej) oraz wyizolowany znak wodny $\mathrm{z}$ rozmytego obrazu (po prawej) oznakowanego metodą DWT-SVD.

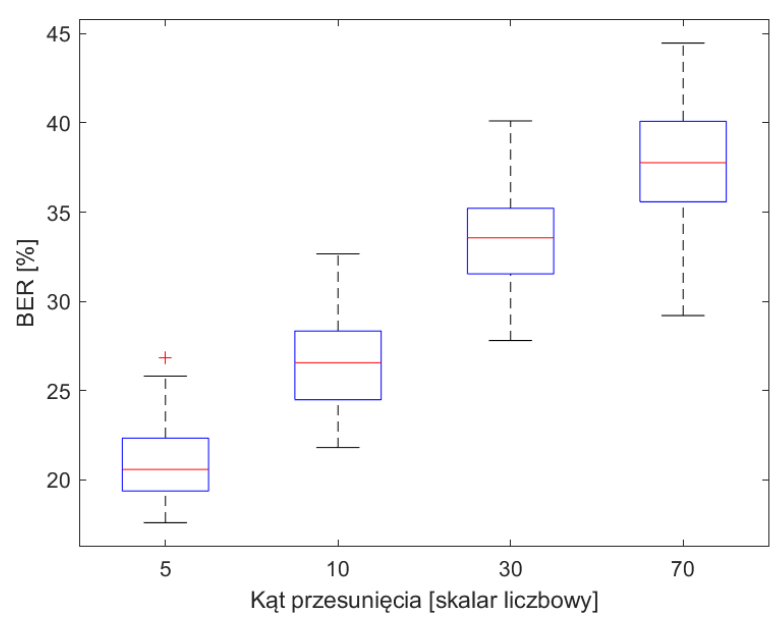

Rysunek 13: Wykres zależności wartości wskaźnika BER od kąta obrotu obrazu dla metody DWT.

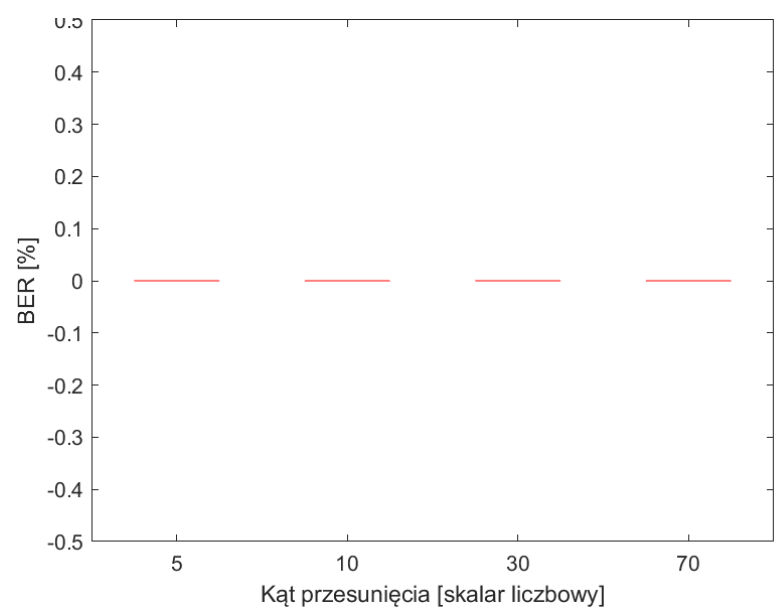

Rysunek 14: Wykres zależności wartości wskaźnika BER od kąta obrotu obrazu dla metody SVD. 


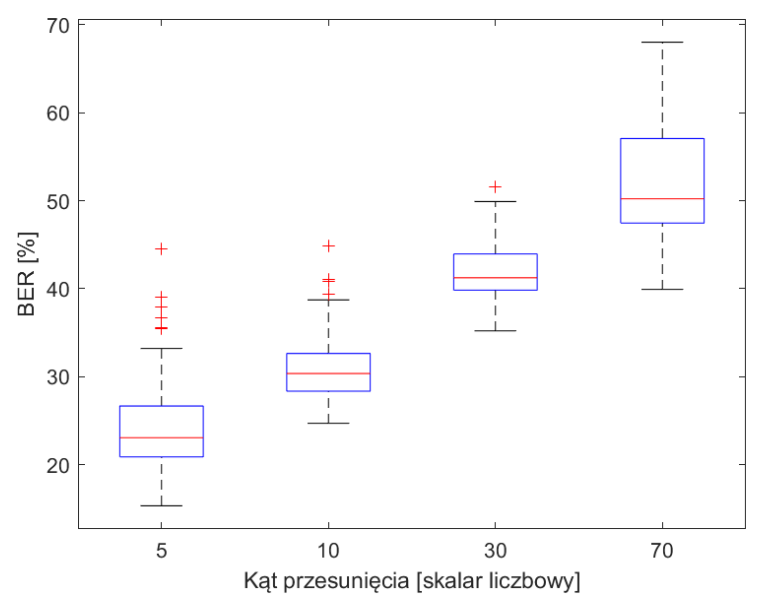

Rysunek 15: Wykres zależności wartości wskaźnika BER od kąta obrotu obrazu dla metody DWT-SVD.

\section{Szybkość}

Ostatnim kryterium oceny była szybkość wykonywania operacji znakowania wodnego oraz ekstrakcji. Jako znak wodny za każdym razem zastosowano logo Politechniki Lubelskiej o rozmiarze 100KB. Wybrano 30 obrazów

o rozmiarze $100 \mathrm{~KB}$ i $20 \mathrm{~KB}$. Badania szybkości powtórzono 20 razy. Odrzucono $10 \%$ wyników najniższych oraz $10 \%$ wyników najwyższych, a następnie obliczono średnie czasy odpowiednich operacji w aplikacji. Rezultaty zaprezentowano w tabeli 5.

Tabela 5: Wyniki badania szybkości wybranych metod znakowania wodnego

\begin{tabular}{|c|c|c|c|c|c|c|}
\hline & \multicolumn{2}{|c|}{ DWT } & \multicolumn{2}{|c|}{ SVD } & \multicolumn{2}{|c|}{ DWT-SVD } \\
\hline $\begin{array}{c}\text { Rozmiar obrazów } \\
{[\text { KB] }}\end{array}$ & 20 & 100 & 20 & 100 & 20 & 100 \\
\hline $\begin{array}{c}\text { Średni czas znako- } \\
\text { wania } \\
{[\mathrm{s}]}\end{array}$ & 0,09 & 0,12 & 0,06 & 0,10 & 0,13 & 0,18 \\
\hline $\begin{array}{c}\text { Średni czas izolo- } \\
\text { wania znaku } \\
{[\mathrm{s}]}\end{array}$ & 0,05 & 0,05 & 0,08 & 0,08 & 0,06 & 0,08 \\
\hline
\end{tabular}

Najkrótszy średni czas procesu znakowania obrazu osiągnęła metoda SVD. Zarówno w przypadku obrazu o rozmiarze $20 \mathrm{~KB}$, jak i 100KB średnie czasy były krótsze niż pozostałych badanych technik. Najwolniejsza okazała się metoda DWT-SVD, ponieważ średni czas znakowania obrazu wynosi 0,13 dla obrazów o rozmiarze $20 \mathrm{~KB}$ oraz 0,18 s dla obrazów o rozmiarze 100KB. Czasy osadzania znaku wodnego są około dwukrotnie większe niż techniki SVD. Najszybciej proces izolacji znaku wodnego wykonuje się algorytmem DWT, a najdłużej - SVD.

\section{Wnioski}

Postawiona teza badawcza "Istnieją metody znakowania wodnego obrazów medycznych pozwalające na uzyskanie odporności na popularne przekształcenia graficzne" została potwierdzona. Ataki przekształcenia przeprowadzone na obrazie oznakowanym metodą SVD nie zniekształciły znaku wodnego zamieszczonego w obrazie źródłowym. Z każdego zaatakowanego obrazu udało się wyekstrahować nienaruszony znak. Niską skutecznością wykazywało się połączenie metod DWT-SVD. Metoda DWT w każdym z przebadanych obrazów nie była odporna na popularne przekształcenia graficzne. Uzyskane wyniki nie potwierdziły więc doniesień znalezionych w artykułach naukowych. W przeprowadzonych badaniach wykazano największą odporność znaków wodnych umieszczonych za pomocą metody SVD.

Teza "Dobór odpowiedniego algorytmu znakowania wodnego pozwala na uzyskanie wysokiej przezroczystości osadzonego znaku wodnego", również została potwierdzona. Jak wykazano przeźroczystość znaku wodnego zależy od zastosowanego algorytmu znaku wodnego. Najlepsze wyniki uzyskała metoda SVD oferując wysoki stopień przezroczystości dołączonych danych co potwierdziły zarówno testy numeryczne jak i ocena wizualna. Na obrazach oznakowanych metodą DWT można zauważyć kontury znaku wodnego. Jest to szczególnie widoczne na ciemnym tle obrazów rentgenowskich. Natomiast obrazy, w których został umieszczony znak wodny metodą SVD, wizualnie nie różniły się od obrazów źródłowych. Niemniej jednak każda $\mathrm{z}$ metod wprowadziła zniekształcenia do znakowanych obrazów, co potwierdzają uzyskane wyniki numeryczne.

Podsumowując, SVD wykazuje się znakomitą odpornością na popularne ataki przekształcenia. Metodę cechuje najkrótszy średni czas procesu znakowania, jednak jest najmniej wydajna pod względem izolacji znaku wodnego z obrazu. Wizualnie ciężko jest dostrzec różnice pomiędzy obrazami znakowanymi metodą SVD, a źródłowymi. Na podstawie wyników wskaźników miar jakości zdjęć również cechuje się najlepszą jakością obrazu spośród wszystkich trzech metod. Natomiast metoda DWT uzyskała najlepszy czas izolacji znaku wodnego. Jednak nie była odporna na popularne ataki przekształcenia oraz jakość obrazu oznakowanego tą metodą była najgorsza. Hybryda DWT-SVD otrzymywała zazwyczaj uśrednione wyniki. Nie była odporna na duże kąty obrotu, czy duże rozmycie - jednak przy małych wartościach była w stanie odtworzyć znak wodny.

\section{Literatura}

[1] A. Anand, A. K. Singh, An improved DWT-SVD domain watermarking for medical information security. Computer Communications, 152 (2020) 72-80.

[2] A. Anand, A. K. Singh, Watermarking techniques for medical data authentication: a survey. Multimedia Tools and Applications 313 (2020) 1-33.

[3] S. M. Arora, A DWT-SVD based robust digital watermarking for digital images. Procedia computer science, 132 (2018) 1441-1448.

[4] M. Begum, M. S. Uddin, Digital Image Watermarking Techniques: A Review. Information, 11(2) (2020) 110.

[5] B. V. Bhalerao, R. R. Manza, Y. M. Rajput, Use of quality measures for rural indian fingerprint image database enhancement and improve the recognition rate. International Journal of Computer Applications, 70(18) (2013) 13-15. 
[6] P. Garg, R. R. Kishore, Performance comparison of various watermarking techniques. Multimedia Tools and Applications, 79(35) (2020) 25921-25967.

[7] Internetowa baza zdjęć medycznych: https://medpix.nlm.nih.gov/home, [22.03.2021r.]

[8] Internetowa społeczność naukowców i praktyków uczenia maszynowego: https://www.kaggle.com, [22.03.2021r.]

[9] F. Kahlessenane, A. Khaldi, R. Kafi,, S. Euschi, A DWT based watermarking approach for medical image protection. Journal of Ambient Intelligence and Humanized Computing, 12(4) (2020) 1-8.

[10] Y. H. Liu, K. F. Yang, H. M. Yan, No-Reference Image Quality Assessment Method Based on Visual Parameters. Journal of Electronic Science and Technology, 17(2) (2019) 171-184

[11] A. Ray, S. Roy, Recent trends in image watermarking techniques for copyright protection: a survey. International Journal of Multimedia Information Retrieval, 9(4) (2020) 1-22.

[12] U. Sara, M. Akter, M. S. Uddin, Image quality assessment through FSIM, SSIM, MSE and PSNR- a comparative study. Journal of Computer and Communications, 7(3) (2019) 8-18.

[13] A. Shehab, M. Elhoseny, K. Muhammad, A. K. Sangaiah, P. Yang, H. Huang, G. Hou, Secure and robust fragile watermarking scheme for medical images. IEEE Access, 6 (2018) 10269-10278.

[14] R. Mironov, S. Kushlev, Medical Images Watermarking using Wavelet Transform and DCT. In LIII International Scientific Conference on Information, Communication and Energy Systems and Technologies, Sozopol , 2018.

[15] M. S. El_Tokhy, Development of optimum watermarking algorithm for radiography images. Computers \& Electrical Engineering, 89 (2021) 106932.

[16] H. Lala, Digital image watermarking using discrete wavelet transform. International Research Journal of Engineering and Technology, 4(1) (2017) 1682-1685. 